\title{
REHABILITASI MEDIK PADA SINDROM MARFAN
}

\author{
Drahma Kusmarwaty \\ Theresia I. Mogi
}

\author{
Program Studi Ilmu Kedokteran Fisik dan Rehabilitasi \\ Fakultas Kedokteran Universitas Sam Ratulangi/BLU RSUP Prof. Dr. R. D. Kandou \\ Manado \\ Email: choez_@hotmail.com
}

\begin{abstract}
Marfan Syndrome (MS) is an autosomal dominant condition of the connective tissue that involves the ocular, cardiovascular and musculoskeletal systems. MS is caused by mutations in the fibrillin-1 gene, leading to joint ligaments flaccidity, joint hypermobility and overgrowth of the long bones. The diagnosis of MS is confirmed by using the Ghent nosology, through a comprehensive assessment largely based on a combination of major and minor clinical manifestations in various organ systems and the family history. The management of MS done with collaboration of team genetic clinic, cardiovascular, orthopedic, eye, and rehabilitation. The aims of rehabilitation of MS patients are to increase pulmonary function, improve exercise endurance, increases bone density, physical strength, prevent scoliosis, education about functional training on activity daily living.
\end{abstract}

Keywords: Marfan syndrome, management, team rehabilitation

\begin{abstract}
Abstrak: Sindrom Marfan (SM) adalah autosom dominan dari jaringan ikat yang melibatkan ocular, kardiovaskular dan sistem musculoskeletal. Penyebab SM adalah mutasi dari gen fibrillin-1, yang menyebabkan flaccid ligamen sendi, hipermobilitas sendi dan overgrowth dari tulang panjang. Diagnosis dari SM dengan Ghent nosology, melalui penilaian secara menyeluruh berdasarkan kombinasi dari manifestasi klinik mayor dan minor pada sistem organ dan riwayat keluarga. Penanganan SM dilakukan dengan kolaborasi tim antara lain klinik genetik, kardiovaskular, orthopedi, mata, dan tim rehabilitasi. Tujuan dari rehabilitasi pada SM adalah meningkatkan fungsi paru, meningkatkan ketahanan latihan, meningkatkan densitas tulang, ketahanan fisik, mencegah skoliosis, edukasi mengenai functional training pada aktivitas kehidupan sehari-hari.
\end{abstract}

Kata kunci: sindrom Marfan, penanganan, tim rehabilitasi

Sindrom Marfan (SM) adalah gangguan sistemik dari jaringan pengikat yang disebabkan oleh mutasi gen FBN1 pada kromosom 15 yang mengatur pembentukan protein fibrilin $1 .^{1,2}$ Walaupun patogenesis SM belum sepenuhnya diketahui, mutasi gen tersebut telah disepakati merupakan penyebabnya. Fibrilin ialah protein matriks ekstrasel yang membentuk komponen utama dari mikrofibril matriks ekstrasel pada kedua jaringan pengikat elastik dan non-elastik. $^{2,3}$
Insiden SM sekitar 2-3 per 10000 individu, meskipun angka tersebut tergantung dari skrining individu yang terkena dan dikenali secara genetik. ${ }^{1,4}$ Prevalensi dari SM antara 1 pada 5.000 sampai 1 pada 10.000 bayi yang baru lahir, dan mengenai semua jenis kelamin. ${ }^{2}$ Individu dengan SM mempunyai harapan hidup sampai usia 32 tahun dan tergantung pada beratnya keadaan kardiovaskular. Dengan mengoptimalkan medikamentosa seperti penggunaan beta bloker dan operasi 
yang selektif usia dapat mencapai 72 tahun meskipun pasien akan memerlukan tim medis yang profesional, termasuk rehabilitasi medik.

\section{DIAGNOSIS}

Kriteria diagnosis SM berdasarkan Ghent dengan kriteria klinik mayor dan minor pada setiap sistem organ yang mungkin terkena (Tabel 1$){ }^{2}$

\section{PENATALAKSANAAN}

Penanganan pasien dengan SM yang optimal dilakukan dengan kolaborasi tim antara klinik genetik, kardiovaskular, ortopedi, mata, dan tim rehabilitasi. Dianjurkan tim rehabilitasi medik yang terdiri dari fisioterapi, okupasi terapi, ortotik prostetik, psikologi dan sosial medik. $^{6}$

Tabel 1. Kriteria diagnosis $\mathrm{SM}^{2}$

\begin{tabular}{|c|c|c|}
\hline Sistem organ & Kriteria mayor & Kriteria minor \\
\hline Sistem skeletal & $\begin{array}{l}\text { Empat gejala dibawah ini: } \\
\text { 1. Pectus carinatum } \\
\text { 2. Pectus exacatum yang } \\
\text { memerlukan operasi } \\
\text { 3. Menurunnya rasio segmen } \\
\text { ekstremitas atas dan bawah atau } \\
\text { meningkatknya rasio arm span } \\
\text { to height }(>1.05) \\
\text { 4. Positif wrist and thumb signs } \\
\text { 5. Skoliosis }\left(>20^{\circ}\right) \quad \text { atau } \\
\text { spondylolithesis } \\
\text { 6. Penurunan ekstensi siku }\left(<170^{\circ}\right) \\
\text { 7. Pes planus } \\
\text { 8. Protrusio acetabulae }\end{array}$ & $\begin{array}{l}\text { Satu manifestasi klinik atau dua gejala kriteria } \\
\text { mayor dan dua kriteria minor: } \\
\text { 1. Pectus excavatum } \\
\text { 2. Hipermobilitas sendi } \\
\text { 3. Lengkungan palatum durum meninggi } \\
\text { 4. Gambaran wajah seperti dolicocephaly, } \\
\text { malar hypoplasia, enopthalamus, } \\
\text { retrognathia, fissura palpebra mendatar. }\end{array}$ \\
\hline Sistem okular & Ectopia lentis & $\begin{array}{l}\text { Dua manifestasi klinik dari kriteria minor: } \\
\text { 1. Flat cornea yang abnormal } \\
\text { 2. Meningkatnya axial length of globe } \\
\text { 3. Hipoplasia iris atau hipoplasia otot siliar, } \\
\text { menyebabkan penurunan miosis }\end{array}$ \\
\hline $\begin{array}{l}\text { Sistem } \\
\text { kardiovaskular }\end{array}$ & $\begin{array}{l}\text { Satu manifestasi klinik dari kriteria } \\
\text { dibawah ini: } \\
\text { 1. Dilatasi dari ascending aorta } \\
\text { dengan atau tanpa regurgitasi } \\
\text { dan sinus Valsava } \\
\text { 2. Dissection of the ascending } \\
\text { aorta }\end{array}$ & $\begin{array}{l}\text { Satu manifestasi klinik dari kriteria minor: } \\
\text { 1. Prolapsus katup mitral dengan atau tanpa } \\
\text { regurgitasi } \\
\text { 2. Dilatasi dari arteri pulmonal dengan tidak } \\
\text { adanya stenosis valvular atau perifer atau } \\
\text { penyebab lain pada pasien dengan usia } \\
<40 \text { tahun } \\
\text { 3. Kalsifikasi dari anulus mitral pada pasien } \\
\text { dengan usia <40 tahun } \\
\text { 4. Dilatasi atau dissection dari descending } \\
\text { thoracic atau annulus aorta abdominal } \\
\text { pada pasien dengan usia <50 tahun. }\end{array}$ \\
\hline Sistem respirasi & Tidak ada & $\begin{array}{l}\text { Satu manifestasi klinik dari kriteria minor: } \\
\text { 1. Spontaneous pneumothorax } \\
\text { 2. Apical blebs }\end{array}$ \\
\hline Kulit & Tidak ada & $\begin{array}{l}\text { Satu manifestasi klinik dari kriteria minor: } \\
\text { 1. Stretch mark yang tidak berhubungan } \\
\text { dengan perubahan berat badan, kehamilan } \\
\text { atau stress yang berulang. } \\
\text { 2. Recurrent or incisional hernia }\end{array}$ \\
\hline Dura & $\begin{array}{l}\text { Dural ectasia lumbosakral dengan } \\
\text { gambaran CT atau MRI }\end{array}$ & Tidak ada \\
\hline
\end{tabular}




\section{Fisioterapi}

Tidak ada protokol yang spesifik yang dapat digunakan untuk fisioterapi dalam menangani SM. Fisoterapis harus diperingatkan pada pasien SM dalam penanganan tidak boleh agresif. Dikarenakan pasien SM mempunyai manifestasi klinik yang berbeda, terapi fisik dapat membantu individu yang mengalami gangguan pada muskuloskeletal yang berhubungan dengan SM. Di sini termasuk pes planus, skoliosis, pectus excavatum, dan pectus carinatum. Stretching, penguatan, terapi latihan, modalitas untuk nyeri. Menurut peraturan aktivitas fisik yang dikeluarkan oleh National Marfan Foundation, latihan penting untuk pasien dengan SM. ${ }^{6}$ Peresepan latihan termasuk: intensitas, durasi, frekuensi, tipe latihan dan kemajuan. Keamanan dari peresepan latihan dimonitor dengan denyut jantung, $\mathrm{EKG}$, tekanan darah dan rate of perceived exertion (RPE) (Gambar 1).,

Peresepan latihan berbeda pada setiap pasien dengan SM dikarenakan respon terhadap latihan akan berbeda pada setiap pasien tergantung pada beratnya penyakit, medikamentosa dan perubahan hemodinamik. Level yang rendah atau denyut jantung yang dibatasi, cara yang paling baik dalam penilaian kapasitas fungsional dan respon hemodinamik tanpa menyebabkan stres terhadap sistem kardiovaskular. Jika pasien dalam kondisi kesehatan yang buruk, simple walk test dapat memberikan informasi yang berguna untuk peresepan latihan. Aktivitas yang harus dihindari ialah high impact sports, aktivitas dengan adanya perubahan cepat dimulai dan cepat diakhiri, dan aktivitas isometrik. Tiga aktivitas yang dapat dipilih yaitu berjalan, berenang dan bersepeda. Menurut penelitian, latihan yang ada contact sports dan latihan isometrik dapat menyebabkan resiko dilatasi aorta dan pecahnya aorta. ${ }^{7}$ Sendi yang hipermobil merupakan resiko tinggi cedera selama contact sports. Aktivitas yang membutuhkan acceleration dan deceleration harus dihindari. ${ }^{9}$

\begin{tabular}{|ccc|}
\hline \multicolumn{3}{|c|}{ Borg RPE Scale } \\
\hline Rating & $\%$ Effort & Description \\
\hline 6 & $20 \%$ & Lying in bed \\
\hline 7 & $30 \%$ & $\begin{array}{c}\text { Very, very light sitting } \\
\text { watching TV }\end{array}$ \\
\hline 8 & $40 \%$ & \\
\hline 9 & $50 \%$ & Very light, easy walking \\
\hline 10 & $55 \%$ & Fairly lipht \\
\hline 11 & $60 \%$ & \\
\hline 12 & $65 \%$ & Hard \\
\hline 13 & $70 \%$ & Somewhat hard-steady pace \\
\hline 14 & $75 \%$ & Feel the heart pounding \\
\hline 15 & $80 \%$ & Very hard \\
\hline 16 & $85 \%$ & \\
\hline 17 & $90 \%$ & Very, very hard \\
\hline 18 & $95 \%$ & Exhaustion \\
\hline 19 & $100 \%$ & Final 50 meters of a race \\
\hline
\end{tabular}

Gambar 1. Perceived exertion scale (RPE) $10 .^{8}$

Latihan dinamik dengan intensitas ringan sampai sedang aman dalam hal meningkatkan denyut jantung, stroke volume, dan curah jantung sementara menurunkan peripheral resistance. Direkomendasikan untuk pasien dengan SM kapasitas aerobik sebesar 50\% dan tidak melebihi denyut jantung 110 kali per menit (atau tidak melebihi 100 kali per menit jika pasien menggunakan beta bloker).

Olahraga yang direkomendasikan yaitu: golf, bowling, snorkeling, noncompetitive doubles tennis, dan bersepeda. Lap swimming tidak direkomendasikan karena aktivitas dinamik ini membutuhkan $>70 \%$ maximal oxygen uptake. Pasien dengan SM harus menghindari scuba diving dikarenakan adanya perubahan tekanan atmosfer yang dapat menyebabkan spontaneous pneumothorax. Extreme sports, latihan yang membutuhkan progressive level of exertion selama latihan (ini dibuat untuk maximize aerobic work capacity) dan latihan pada lingkungan yang berbahaya harus dihindari. Latihan pada lingkungan yang berbahaya yaitu humidity mempunyai resiko adanya perubahan pada blood volume, elektrolit, dan hydration. 
Olahraga diatas $50 \%$ kapasitas aerobik akan menyebabkan stress terhadap sistem kardiovaskular. $^{9}$

\section{Okupasi terapi}

Peran okupasi terapi (OT) pada kondisi ini adalah memberikan edukasi kepada pasien mengenai functional training yaitu bagaimana cara melaksanakan aktivitas kehidupan sehari-hari (AKS) dengan nyaman tanpa harus disertai dengan gejala sesak nafas, cepat letih dan ritme jantung yang tidak teratur. ${ }^{10}$

Secara umum tujuan pelaksanaan OT adalah memperbaiki dan memaksimalkan kemandirian penderita dalam melaksanakan AKS yaitu (1) meminimalkan short of breath pada saat melakukan AKS (2) mencapai pola pernafasan yang efektif (3) Meningkatkan daya tahan dalam melaksanakan AKS (4) Penerapan pengelolaan energi dan waktu (5) Mengajarkan relaksasi dan teknik pengelolaan stres (6) Meningkatkan kesadaran untuk menggunakan adaptasi peralatan (7) Membantu pasien dan keluarga dalam mendidik pengelolaan AKS setelah keluar dari rumah sakit dan (8) Mengeksplorasi persoalan yang berhubungan dengan pekerjaan. ${ }^{10}$

Teknik energi konservasi dan penyederhanaan kerja untuk kondisi seperti ini antara lain: ${ }^{10}$

1. Menggunakan prinsip body mekanik dengan benar

-Menjaga kelurusan tulang belakang saat beraktivitas

- Menggunakan otot yang besar dan sinergis dalam beraktivitas, terutama saat mengangkat beban.

-Menggunakan kedua tangan bila memungkinkan

-Menjaga keseimbangan yang kokoh

2. Mengorganisasi dan membatasi jumlah pekerjaan

3. Menggunakan metode efisiensi

-Berikan edukasi kepada pasien untuk menggunakan alat bantu, adaptasi alat saat melakukan AKS.

4. Lakukan aktivitas dengan duduk bila memungkinkan
5. Istirahat yang cukup setelah melakukan aktivitas

\section{Penerapan konservasi energi dan penyederhanaan kerja pada AKS}

Disini diberikan edukasi mengenai kondisi atau penyakitnya, penerapan konservasi energi dan penyederhanaan kerja, modifikasi lingkungan dalam melakukan suatu aktivitas yang akan dikerjakan oleh pasien dalam AKS.

\section{Bathing and toileting}

-Kamar mandi dan toilet sebaiknya dalam satu ruangan

-Melengkapi dinding kamar mandi dengan grab bars untuk safety dan memudahkan/meringankan saat bangkit dari dudukan.

-Menggunakan toilet duduk

-Menggunakan shower saat mandi atau selang

-Menggunakan long handle bath sponge untuk menggosok/ menyabun bagian tubuh yang sulit dijangkau

-Menggunakan handuk jubah sehingga tinggal memakai seperti baju tidur. Handuk jubah digunakan untuk mengeringkan tubuh

-Bila memungkinkan gunakan sikat gigi elektrik

-Tempat sabun harus mudah dijangkau oleh tangan dan tidak melebihi tinggi kepala

-Jangan membuat gantungan baju melebihi tinggi kepala

\section{Dressing}

-Memakai dan melepas celana, kaos kaki, dan sepatu dalam posisi duduk

-Hindari memakai pakaian yang cara memakainya melewati kepala

-Pada saat memakai kutang, cara mengancingkannya di depan kemudian baru diputar ke belakang.

-Hindari pakaian dengan kancing dibelakang

-Lemari pakaian jangan terlalu tinggi atau terlalu rendah 


\section{Grooming}

-Berhias dengan posisi duduk

-Model rambut sebaiknya yang mudah dalam perawatan

-Menggunakan alat cukur (razor) yang tajam

-Gunakan long handle attachment pada sisir untuk mengurangi jangkuan lengan melebihi bahu

\section{Washing}

-Gunakan mesin cuci bila memungkinkan

-Gunakan jasa laundry atau bantuan orang lain untuk mencuci pakaian dari bahan yang berat

-Apabila mencuci secara manual, usahakan dalam posisi duduk

-Jemuran pakaian tidak boleh melebihi tinggi kepala

\section{Bed making}

-Duduk di tempat tidur saat mengganti sarung bantal dan guling

-Hindari gerakan terlalu banyak memutar badan

-Lakukan kontrol pernafasan saat melakukan komponen aktivitas

-Pada waktu merapikan seprai atau selimut inhalasi biasa kemudian lakukan ekshalasi pursed lip pada waktu menarik seprai/selimut, mulai inhalasi lagi dan saat ekshalasi masukkan sudut seprai/bagian tepi selimut di bawah kasur

\section{Shopping}

-Minta bantuan penjaga toko untuk mengangkat barang belanjaan

-Gunakan kereta dorong untuk mengumpulkan belanjaan

-Belanja lewat telepon, katalog, atau internet bila memungkinkan

\section{Cooking and meal preparation}

-Gunakan kompor yang disesuaikan dengan tinggi pasien

-Jangan menggunakan peralatan memasak yang berat
-Memasak makanan dengan porsi yang dilebihkan (ekstra) agar tidak terlalu sering memasak dalam sehari

-Istirahat setelah melakukan satu rangkaian aktivitas

\section{Driving}

-Gunakan fasilitas drive and shop pada toko atau supermarket tertentu

-Dapatkan handicapped sticker untuk memudahkan atau mendapatkan tempat parkir yang lebih dekat

-Hindari mengendarai mobil pada jam sibuk untuk menghindari kemacetan.

\section{Ortotik prostetik}

Penggunaan splint dan atau wrap untuk menyokong dan menstabilkan lax joint saat melakukan aktivitas. Splint ini digunakan untuk menyokong/menstabilkan proximal lax joint sementara meningkatkan fungsi pada distal. Sebagai contoh splint: static wrist splints, CMC thumb splints, buddy straps, digit positioning splints sama seperti wrist and thumb wraps. Splint di rancang sebagai tambahan dalam latihan aktif atau program AKS. Night positoning splints sama seperti mobilisasi splint digunakan bila ada gangguan pada kontraktur dari siku dimana biasanya akan mengenai SM. ${ }^{6}$

Penggunaan back brace direkomendasikan bila sudut skoliosis antara $20^{\circ}$ dan $40^{\circ}$. Bagaimanapun, brace tidak membantu secara permanen meluruskan kurva. Bila brace dilepas, spine akan kembali pada posisi semula. Tujuan menggunakan brace adalah menjaga kurva tidak memburuk. Waktu pemakaian 23 jam per hari. Brace dipakai sampai pertumbuhan tercapai. Untuk anak perempuan, biasanya usia 14 atau 15; sedangkan untuk anak laki-laki usia 16 atau 17. Penanganan konservatif menggunakan brace efektif dalam mencegah meningkatnya kurvatura pada pasien idiopatik tetapi tampaknya kurang efektif pada pasien SM dengan skoliosis. Penanganan operasi untuk pasien SM dengan skoliosis menjadi sangat sulit 
dikarenakan berbagai macam gangguan anatomi. $^{11}$

Pada bagian kaki, pasien SM memiliki kaki panjang dan kurus. Bentuk dari kaki bervariasi, tetapi kebanyakan, lengkungan longitudinal lebih rata dibandingkan orang normal. Arch support tidak akan membuat flat foot menjadi ada lengkungan, tetapi dapat meningkatkan gait. Nyeri pada kaki sering terjadi pada pasien, special cushion, inserts akan membantu. Memakai sepatu dengan heel yang rendah, atau tidak ada heel lebih direkomendasikan. ${ }^{11}$

\section{Psikologi}

Pasien dengan SM terlihat dan merasa berbeda. Ketidakhadiran di sekolah atau di tempat kerja kadang sering terjadi. Meskipun intelektual dan perkembangan motorik kasar normal, pasien gagal menunjukkan kemampuannya dikarenakan keterbatasan fisik. $^{12}$

Anak dengan SM memberikan masalah kepribadian yaitu kuatir, cemas dan depresi, tetapi mereka tidak dapat mengeluarkan masalah mereka sehingga mereka menjadi antisosial. Pada masa pubertas, dikarenakan mereka berbeda dengan teman sebayanya kadang mereka diolok-olok dan disisihkan. Faktor lainnya yang dapat menjadi masalah psikologi yaitu sangat bergantung kepada orangtua dan cepat lelah sehingga membatasi pekerjaan. Disarankan orangtua dan guru mengetahui dan membangun kepercayaan diri dan interaksi sosial. Contoh membangun kepercayaan diri dengan membangun kemampuan seni, musik, atau komputer. ${ }^{12}$

\section{SIMPULAN}

Sindrom marfan (SM) adalah gangguan autosom dominan dari jaringan ikat yang melibatkan gen fibrillin-1, yang memengaruhi berbagai sistem organ, antara lain sistem muskuloskeletal, kardiovaskular, dan okular.

Diagnosis SM ditegakkan dengan Ghent nosology melalui penilaian secara menyeluruh berdasarkan kombinasi dari manifestasi klinik mayor dan minor pada sistem organ dan riwayat keluarga.
Penanganan SM dilakukan dengan kolaborasi tim antara lain klinik genetik, kardiovaskular, orthopedi, mata, dan tim rehabilitasi.

\section{DAFTAR PUSTAKA}

1. Judge DP, Dietz HC. Marfan syndrome. Lancet. 2005;366 (9501):1965-76.

2. Canadas V, Villacosta I, Bruna I, Fuster V. Marfan syndrome part 1: Pathophysiology and diagnosis. Natural Review Cardiology. 2010;10:1-9.

3. Frydman M. The Marfan syndrome. IMAJ. 2008; $10: 175-8$

4. Giske L, Stanghelle JK, Hendrikssen SR, Strom V, Wilhelmsen JE, Roe C. Pulmonary function, working capacity and strength in young adults with Marfan syndrome. 2003;35:221-8.

5. Cipriano GFB, Brech GC, Peres PAT, Mendes CC, Junior GC, Carvalho ACC. Anthropometric and musculoskeletal assessment of patients with Marfan syndrome. Revista Brasileria de Fisioterapia. 2011;15(4):291-306.

6. Paris MJ. Standard of care: Marfan syndrome. 2009. [cited 2013 July 14]. Available from: http://www.brighamandwomens.org/Pat ients_Visitors/pcs/rehabilitationservices /Occupational\%20Therapy\%20Standar ds $\% 20$ of $\% 20$ Care-

Protocols/General\%20\%20Marfan\%20Syndrome\%20OT.

7. Lopez R, McGraw JB. Marfan syndrome in a female collegiate basketball player: A case report. Journal of Athletic Training. 2000;35(1):91-5.

8. Rate Perceived Exertion Chart [image on the internet). c2011 [updated 2014; cited 2014 November 10]. Available from : http://driverlayer.com/img/exertion/144 /web

9. Dennison AD, Certo C. Exercise for individuals with Marfan syndome. Cardiopulmonary Physical Therapy Journal. 2006;17(3):110-6.

10. Kurniawan A. Konservasi Energi dan Penyederhanaan Kerja pada Kondisi Kardiorespirasi. Jakarta, 2002.

11. Avivi E, Arzi H, Paz L, Caspi I, Chechik A. Skeletal Manifestations of Marfan Syndrome. IMAJ. 2008; 10: 186-188. 
12. Hofman KJ, Bernhard BA, Pyertiz RE. Marfan syndrome: neuropsychological aspects. American Journal of Medical Genetics. 1998;31:331-8. 